\title{
Effects of sandblasting of prosthetic abutment surfaces on the tensile strength of cement-retained crowns, using a cementing technique: an in vitro study
}

\author{
- Fernando Igai School of Dentistry, University of São Paulo, São Paulo, SP, Brazil • Matsuyoshi Mori Prosthesis Department, \\ School of Dentistry, University of São Paulo, São Paulo, SP, Brazil • Ivo Contin Prosthesis Department, School of Dentistry, \\ University of São Paulo, São Paulo, SP, Brazil • Washington Steagall Junior Discipline of Restorative Dentistry, Nove de \\ Julho University, São Paulo, SP, Brazil • Pedro Tortamano Neto Prosthesis Department, School of Dentistry, University of São \\ Paulo, São Paulo, SP, Brazil
}

ABSTRACT | Objective: The tensile strength effects on the sandblasting of the abutment associated with a cementing technique are not well documented. The objective of this study is to analyze the tensile strength of prosthetic crowns cemented on standard and sandblasted abutments, using a cementing technique. Methods: Experimental groups were formed according to cementing technique (control and practice abutment technique) and prosthetic abutment roughness (standard and sandblasted), totaling forty specimens. The crowns were cemented with Zinc Phosphate cement. Statistical analysis was conducted with an $\alpha$ at 0.05. Results: Considering the cementation techniques analysis, there were no statistically significant differences between the groups, with mean tensile strength values of $157.83 \pm 22.16 \mathrm{~N}$ for the control technique, and $159.95 \pm 46.40 \mathrm{~N}$ for the practice abutment technique on the standard surface. Result analysis of the control technique $(626.23 \pm 34.80 \mathrm{~N})$ and practice abutment technique $(642.62 \pm 94.00 \mathrm{~N})$ indicated no significant differences on the sandblasted surface. Considering the surface roughness analysis, significant differences were observed, with values of $157.83 \pm 22.16 \mathrm{~N}$ for the control technique/standard surface group and $626.23 \pm 34.80 \mathrm{~N}$ for the control technique/sandblasted surface group. Significant differences were observed in the practice abutment technique/standard surface group with $159.95 \pm 46.40 \mathrm{~N}$ values, compared to the $642.62 \pm 94.00 \mathrm{~N}$ value for the practice abutment technique/sandblasted group. Conclusions: The practice abutment cementing technique showed no significant differences with the control technique, regarding to the tensile strength, in the two surfaces (standard and sandblasted) used in the study. The sandblasting of prosthetic abutments led to a significant increase on the tensile strength considering the two studied cementation techniques.

DESCRIPTORS | Tensile Strength; Dental Prosthesis; Cementation; Dental Materials.

RESUMO | Efeitos da asperização da superfície do munhão protético na resistência à tração de coroas cimentadas, utilizando uma técnica de cimentação: um estudo in vitro - Objetivos: Os efeitos de resistência à tração no jateamento do pilar associado a uma técnica de cimentação não estão bem documentados. O objetivo deste estudo é analisar a resistência à tração de coroas protéticas cimentadas em munhões padrões e asperizados, utilizando uma técnica de cimentação. Métodos: Os grupos experimentais foram formados de acordo com a técnica de cimentação (técnica de controle e prática de pilares) e a rugosidade do pilar protético (padrão e asperizado), totalizando quarenta espécimes. As coroas foram cimentadas com cimento de fosfato de zinco. A análise estatística foi conduzida a um valor de $\alpha=0,05$. Resultados: Na análise das técnicas de cimentação não houve diferenças estatisticamente significativas

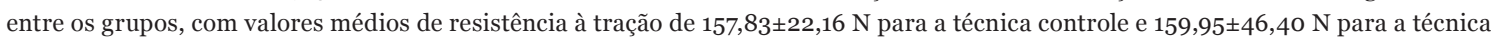
practice abutment na superfície padrão. A análise dos resultados na técnica controle $(626,23 \pm 34,80 \mathrm{~N})$ e na técnica practice abutment $(642,62 \pm 94,00 \mathrm{~N})$, na superfície jateada, também não indicaram diferenças significativas. Na análise da rugosidade da superfície, observaram-se diferenças significativas, com valores de $157,83 \pm 22,16 \mathrm{~N}$ para o grupo técnica controle/superfície padrão e $626,23 \pm 34,80$ N para o grupo técnica controle/superfície asperizada. Foram observadas diferenças significativas no grupo técnica Practice abutment/ superfície padrão com valores de 159,95 46,40 N comparado com o grupo técnica Practice abutment/grupo jateado, com valores de 642,62 $\pm 94,00$ N. Conclusões: A técnica de cimentação Practice abutment não mostrou diferenças significativas com a técnica controle, em relação à resistência à tração, nas duas superfícies (padrão e asperizada) usadas no estudo. O jateamento dos munhões protéticos levou a um aumento significativo da resistência à tração nas duas técnicas de cimentação estudadas.

DESCRITORES | Resistência à Tração; Prótese Dentária; Cimentação; Materiais Dentários.

CORRESPONDING AUTHOR | • Fernando Igai School of Dentistry, University of São Paulo • Av. Professor Lineu

Prestes, 2227 São Paulo, SP, Brazil • 05508-000 E-mail: igai@usp.br

- Received Apr. 10, 2017 • Accepted May 5, 2017

- Dol http://dx.doi.org/10.11606/issn.2357-8041.clrd.2017.130950 


\section{INTRODUCTION}

The significant success of osseointegrated implants have increased the use of cement-retained prostheses, making them a good treatment option, ${ }^{1}$ as well as screw-retained prostheses, which can be indicated as a highly reliable treatment concept. ${ }^{2}$ Cement-retained prostheses have many advantages, such as ease of fabrication, easier way to achieve prosthetic crown passivity, better aesthetic, occlusal stability, among others. Screw-retained prostheses still have a major benefit, which is the retrievability. ${ }^{3-5}$ The retrievability was extremely useful when rehabilitation treatments used to have a high degree of maintenance, or even due to tissue instability and possible complications arising from the implants installation. However, Implantology has evolved, and the use of implants with high degree of clinical success, along with established concepts, such as platform switching and Morse taper connections implants, has led Implantology into a highly reliable and predictable specialty, with levels of success over $90 \%{ }^{6}$, and a $85.5 \%$ rate of "complication-free" prostheses.7 This fact, combined with the use of implants to replace a single element, has consecrated the use of cement-retained prostheses, and led to the use of screw-retained prostheses in full or partial arch fixed reconstructions.

A major shortcoming of cement-retained prostheses is the excess of cement. The accumulation of excess cement around peri-implant tissues may lead to inflammatory reactions and complications, such as pain in the area, bleeding, suppuration in the region and bone loss, as well as possible implant loss and treatment failure. ${ }^{8-9}$

There are cementing techniques that reduce the excess cement around the prosthetic crown; however, they are indicated for prostheses with different gingival levels or subgingival cases. Among these, there is a technique called "practice abutment", described in literature as a method that decreases the excess cement through an easy maneuver, in which a crown filled with cement is installed into an analog component before its cementation on the prosthetic abutment. In this installation, there is an excess cement overflow that can be easily removed with gauze or cotton. After that, a very thin cement thickness can be observed, which promotes efficient retention of the prosthetic crown. ${ }^{10-11}$

Another factor that must be observed when studying cement-retained prosthesis is the influence of the prosthetic abutment surface roughness on the retention force of the prosthesis. The Aluminum Oxide sandblasting promotes a significant improvement in the tensile strength of the crown cemented on this type of surface. This fact is observed when using temporary cements, ${ }^{12}$ resin cements ${ }^{13}$ and especially in Zinc Phosphate cement. ${ }^{14}$ This is due to the nature of its retention, promoted by a mechanical interlock, which increases with the sandblasting of the surface, ${ }^{15}$ leading to a great benefit for the retention force. The sandblasting of the surface is even suitable for use in abutments with small dimensions, to increase the retention force of the crown. ${ }^{16}$ However, the use of the practice abutment cementation technique in sandblasted abutments is little studied. Therefore, a study should be carried out to verify the effects of the association between the practice abutment cementation technique on sandblasted prosthetic abutments.

The aim of this study is to analyze the retention force of the crown cemented on sandblasted prosthetic abutments, comparing with standard prosthetic abutments, using the practice abutment cementing technique and the conventional cementing technique (control technique).

\section{MATERIALS AND METHODS}

This study used Neodent ${ }^{\circledR}\left(\right.$ Neodent $^{\circledR}$, Curitiba, PR, Brazil) calcinable components adapted to a prosthetic analog component with $3.3 \mathrm{~mm}$ in diameter and $4.0 \mathrm{~mm}$ in length, which simulated the prosthetic abutments. Forty prosthetic crowns were 
waxed with a ring on its occlusal surface. Prosthetic abutments replicas were fixed with acrylic resin cylinders, totaling forty specimens (crown/analog component sets). The waxing sequence of the crown and the specimen aspect are shown in Figure 1.

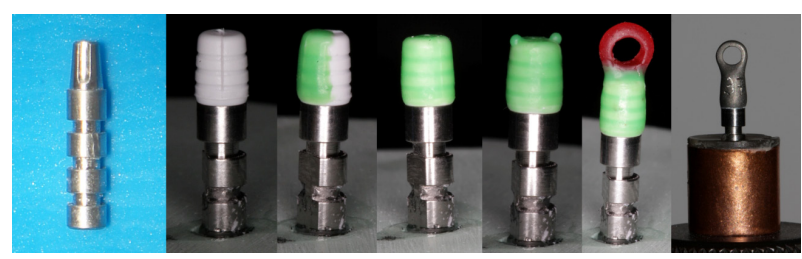

Figure 1 | Waxing sequence of the crown and specimen aspect.

The experimental design consisted of a Model $2^{\mathrm{K}}$, where $\mathrm{K}=2$. The response variable is the retention force measured in Newton (N). The variation factors are: surface roughness, independently, on two levels (standard and sandblasted); and cementing technique, independently, on two levels (practice abutment technique and control technique). The resulting design was $2^{2}$, a total of four experimental conditions, with ten specimens per group $(n=10)$, totaling forty samples and four groups. Group no. 1 had crowns cemented with the control technique on standard metallic abutments; group no. 2 had crowns cemented with the control technique on sandblasted metallic abutments; group no. 3 had crowns cemented with the practice abutment technique on standard metallic abutments; and group no. 4 had crowns cemented with the practice abutment technique on sandblasted metallic abutments.

The sandblasting of the prosthetic abutment was performed using a $150 \mu \mathrm{m}$ Aluminum Oxide, at 4.0 bar, for five seconds. The Zinc Phosphate cement (SSWhite ${ }^{\circledR}$, Rio de Janeiro, RJ, Brazil) was used for cementation of the crown, which was manipulated according to the manufacturer's specifications. After manipulation, the cement was inserted into the crown to fill it completely, standardizing the amount of cement.

Groups no. 1 and no. 2 were cemented with the control technique, in which, after cement insertion, the crowns were seated on the prosthetic abutment with a digital pressure and then received a $50 \mathrm{~N}$ compressive load for ten minutes. The $50 \mathrm{~N}$ compressive load was held using a manual static loading device, which can apply $50 \mathrm{~N}$ in an axial standardized way. Figure 2 shows the $4 \mathrm{~kg}$ of measured weights plus $1 \mathrm{~kg}$ of the moving head of the device, totaling the $5 \mathrm{~kg}(5 \mathrm{O} \mathrm{N})$ static load.

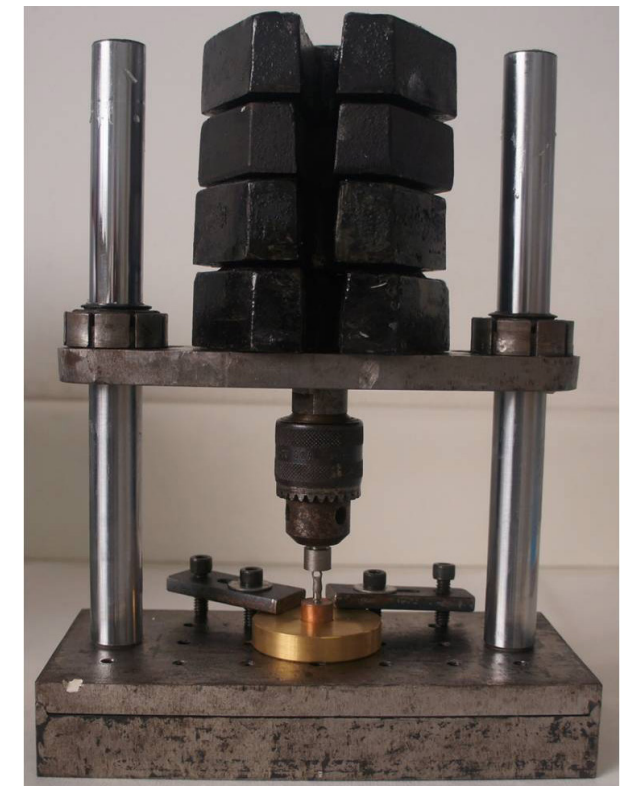

Figure 2 | Manual static loading device (50 N compressive load application).

After crystallization of the cement, the excess cement was removed with a scaler. Groups no. 3 and no. 4 were cemented with the practice abutment cementing technique. In this technique, the crown is installed in an analog component, with dimensions identical to the prosthetic abutment specimen. This maneuver provides a cement extravasation, however the excess cement remains attached on the analog abutment. The crown is immediately removed from the analog component, any excess cement on its surface is cleaned and the crown is cemented on the prosthetic abutment. This procedure was performed for all crowns from groups no. 3 and no.4, which received the same $50 \mathrm{~N}$ static load as groups no. 1 and no. 2, after the cement extravasation 
maneuver. Flowcharts from Figures 3 and 4 illustrate the control technique and practice abutment technique, respectively. Figure 5 shows the cement extravasation maneuver.

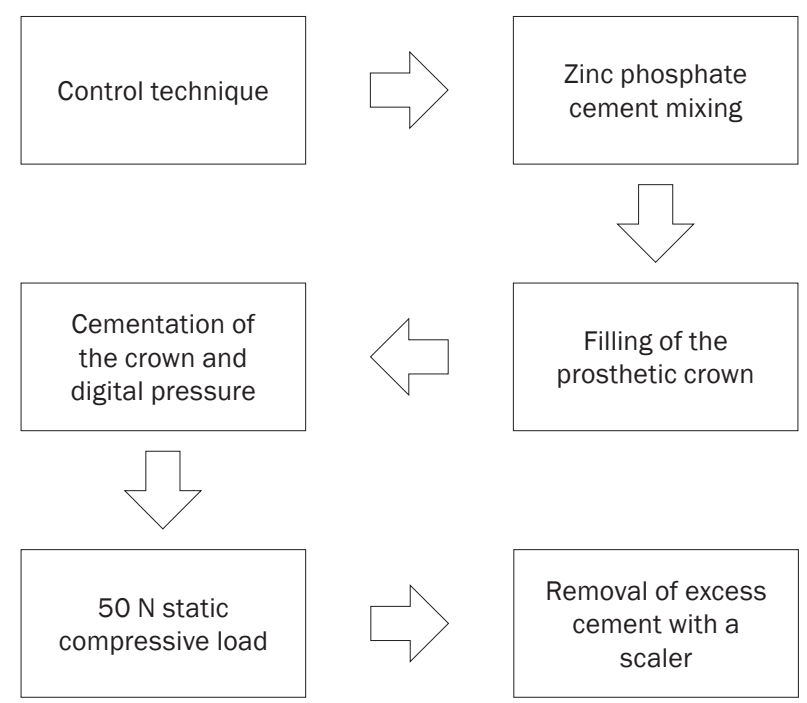

Figure 3 | Control cementing technique flowchart.

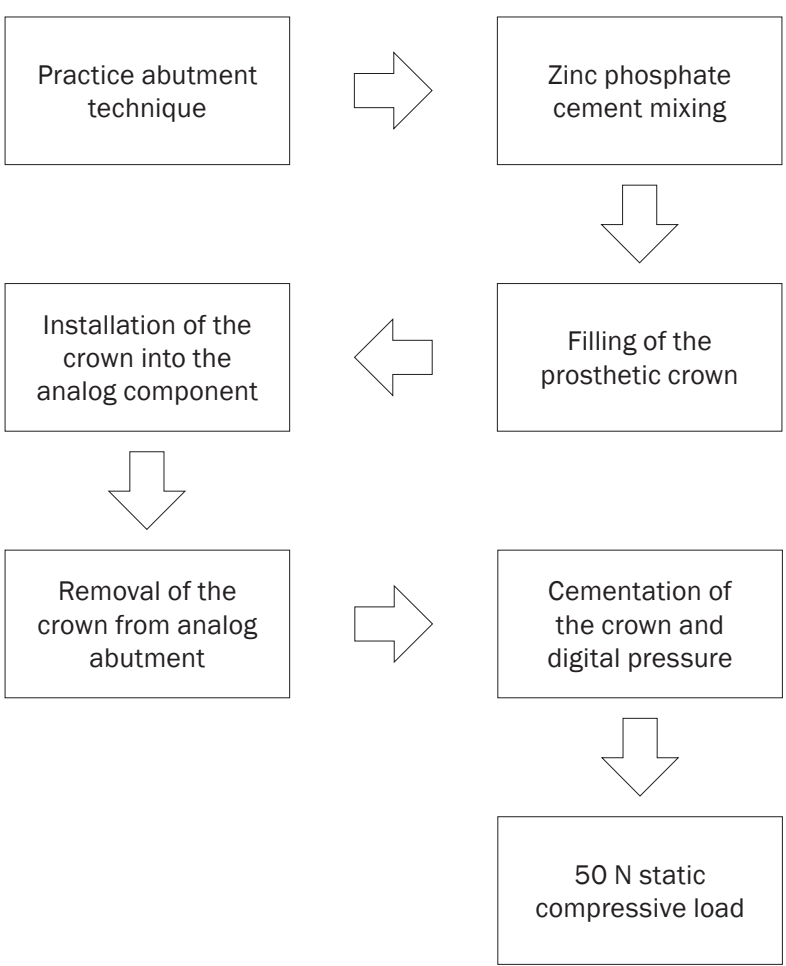

Figure 4 || Practice abutment cementing technique flowchart.

All specimens were subjected a thermal cycling from $5{ }^{\circ} \mathrm{C}$ to $55^{\circ} \mathrm{C}$, for 24 hours. After thermal cycling, each specimen was subjected to the pullout test, using individual adapters developed to conduct this study. A universal testing machine (Kratos Equipamentos, Cotia, SP, Brazil) was used with a $1000 \mathrm{~N}$ load cell at a $0.5 \mathrm{~mm} / \mathrm{min}$ crosshead speed, with a $1 \mathrm{~mm}$ total displacement, until the cementation line fracture, with separation of the prosthetic crown from the abutment. Data were submitted to the Levene's test to verify the assumption of its homogeneity. The test indicated that data were homogeneous $(\mathrm{F}(3 \cdot 31)=1.90, \mathrm{p}=0.17)$. Therefore, the Levene's test accredited the data to submit it to the two-way Analysis of Variance (ANOVA) test (cementation technique versus surface roughness), complemented by Tukey multiple comparison test.

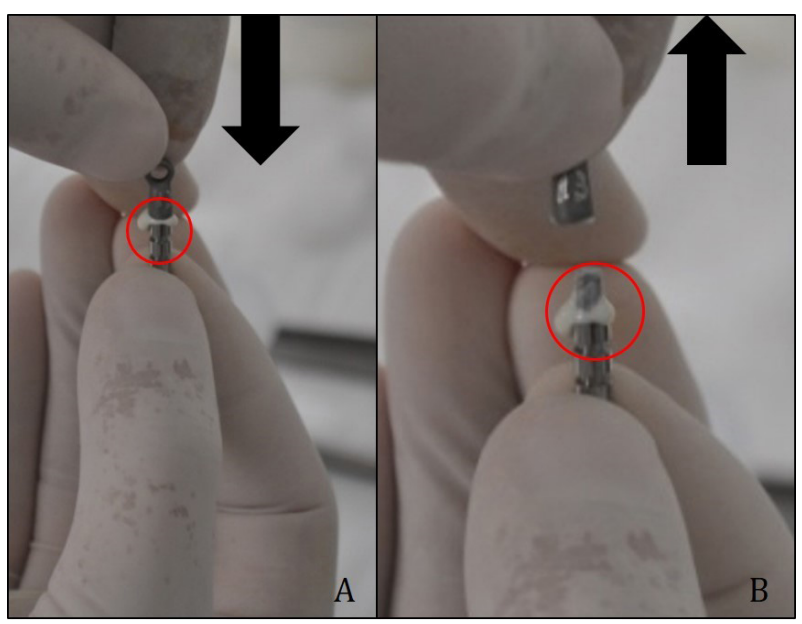

Figure 5 | Cement extravasation maneuver. A. Installation of the crown into analog component; B. Removal of the crown from analog component.

\section{RESULTS}

Table 1 shows data on descriptive statistics. In Table 2, the ANOVA test showed statistical significance for the surface roughness factor $(\mathrm{F}(1.31)=596.58$, $\mathrm{p}=8.23 \mathrm{E}-22)$. The cementing technique factor $(\mathrm{F}(1.31)=0.23, \mathrm{p}=0.64)$ and the interaction between the surface roughness and cementing technique factors $(\mathrm{F}(1.31)=0.13, \mathrm{p}=0.72)$ were not significant. The graph in Figure 6 illustrates the Tukey test, with 95\% confidence intervals, which showed that the tensile strength values from groups no. 4 (642.62 
$\mathrm{N} \pm 93.98 \mathrm{~N})^{\mathrm{A}}$ and group no. $2(626.23 \mathrm{~N} \pm 34.83 \mathrm{~N})$ ${ }^{\mathrm{A}}$ were similar and statistically superior to the group no. $3(159.95 \mathrm{~N} \pm 46.37 \mathrm{~N})^{\mathrm{B}}$ and group no. 1 (157.83 $\mathrm{N} \pm 22.16 \mathrm{~N})^{\mathrm{B}}$, which were similar to each other. No statistically significant differences were observed when comparing the cementing techniques with each other; in other words, the tensile strength values showed no significant differences for both surface roughness factors. Statistically significant differences were observed when comparing the surface treatment. That is, the sandblasting of abutment walls led to a significant increase in the tensile strength of the crowns, cemented by both cementing techniques studied in this experimental section.

Table 1 | Descriptive and statistical parameters of experimental data.

\begin{tabular}{|c|c|c|c|c|c|c|c|c|c|c|c|}
\hline Groups & $n$ & Mean & SE & SD & Var & Min & Max & Q1 (25\%) & Med (50\%) & Q3 (75\%) & VC (\%) \\
\hline no. 2 & 8 & 626.20 & 12.30 & 34.80 & 1213.10 & 566.30 & 666.90 & 597.60 & 627.60 & 657.40 & 5.56 \\
\hline no. 1 & 8 & 157.83 & 7.83 & 22.16 & 491.08 & 139.75 & 202.51 & 140.91 & 148.08 & 172.05 & 14.04 \\
\hline no. 4 & 9 & 642.60 & 31.30 & 94.00 & 8831.70 & 415.80 & 733.10 & 624.70 & 667.80 & 708.00 & 14.62 \\
\hline no. 3 & 10 & 159.90 & 14.70 & 46.40 & 2149.80 & 121.10 & 287.80 & 140.10 & 146.40 & 159.40 & 28.99 \\
\hline
\end{tabular}

SE = Standard error; SD = Standard deviation; Var =Variance; Min = Minimum; Max = Maximum; Q1 (25\%) = First Quartile $(25 \%) ;$ Med $(50 \%)=$ Median (50\%); Q3 (75\%) = Third Quartile (75\%); VC (\%) = Variance coefficient.

Table 2 | Two-way ANOVA test (cementing technique versus surface roughness).

\begin{tabular}{c|c|c|c|c|c|c|} 
Source of variation & SS & df & MS & F calc. & Sig $(p)$. & F crit. \\
\hline Cementing technique & 743.29 & 1 & 743.29 & 0.23 & 0.64 & 4.16 \\
\hline Surface roughness & 1961620.38 & 1 & 1961620.38 & 596.58 & $8.23 E-22 *$ & 4.16 \\
\hline $\begin{array}{c}\text { Cementing technique } \\
\times \text { Surface roughness }\end{array}$ & 441.62 & 1 & 441.62 & 0.13 & 0.72 & 4.16 \\
\hline Error (residual) & 101931.01 & 31 & 3288.10 & & \\
\hline Total & 7410911.62 & 35 & & & \\
\hline
\end{tabular}

$\mathrm{df}=$ degrees of freedom; $\mathrm{SS}=$ sum of squares; $\mathrm{MS}=$ Mean squares; $\mathrm{F}$ calc. = calculated "F"; $\mathrm{F}$ crit. = critical " $\mathrm{F}$ " value.

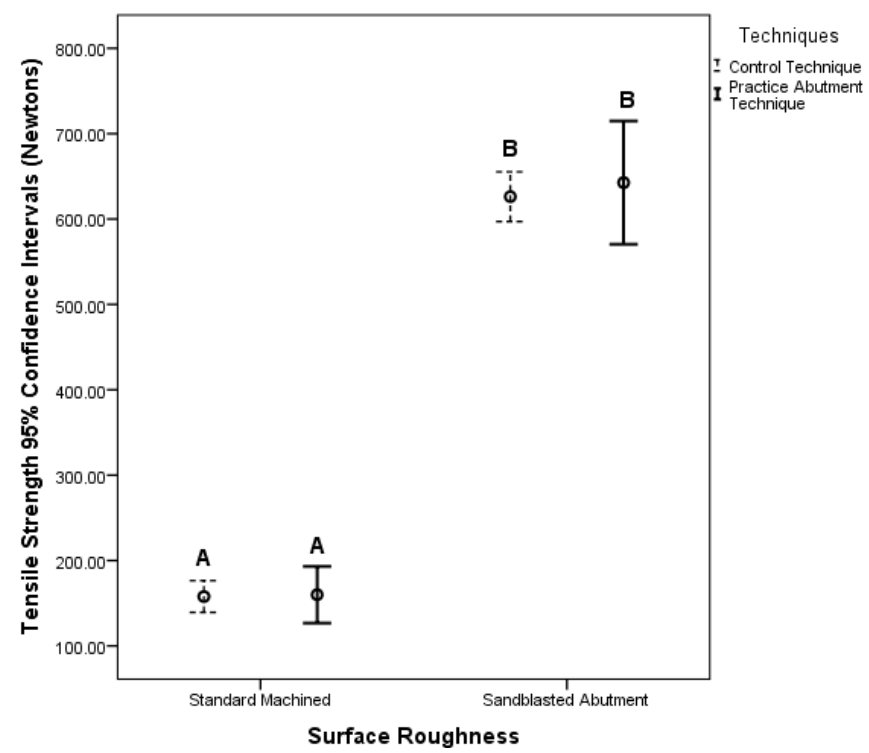

Figure 6 | Dispersion graph of the 95\% confidence intervals for the experimental conditions tested. 


\section{DISCUSSION}

Cement-retained prostheses are qualified as a highly reliable treatment and they have many advantages over screw-retained prosthesis, such as its technical ease and lower cost in manufacturing, among other advantages. Retrievability, the main advantage of the screw-retained prosthesis, is no longer the decisive factor. Predictability of treatments, the high success rate of osseointegrated implants and even the possibility to apply retrievability into cement-retained prostheses, ${ }^{17}$ has led the use of screw-retained prostheses for scenarios of greater complexity or extensive cases. ${ }^{18}$

However, the main shortcoming observed in cement-retained prostheses is the biological problems associated to the excess cement in the periimplant region. We know that cement accumulation in the peri-implant region is associated with incidence of peri-implantitis. ${ }^{19-20}$ Restorations with subgingival margins hinders the cement removal, and the deeper the subgingival restoration margins ( $2 \mathrm{~mm}$ or deeper), the harder the removal of any excess cement. ${ }^{21}$

The first objective of this study was to analyze a cementing technique, known in the literature as practice abutment, which reduces the excess cement around the prosthetic crown, based on a previous study conclusion. ${ }^{11}$ The results obtained in the experimental part of this study indicated that this cementing technique was not inferior in its retentive capacity, when compared with the conventional cementation technique. The application of this cementing technique is particularly interesting when using resin cement. The use of this type of cement can lead to technical difficulties in removing the cement remnants. There is even the possibility of damaging the prosthetic abutment surface, if the dentist uses an inappropriate instrument for its removal. ${ }^{22}$ We know that resin cement has a greater tensile strength when compared to the Zinc Phosphate cement, ${ }^{23}$ which in turn, provides greater ease for its removal. One of the ways to increase the Zinc Phosphate tensile strength is through sandblasting of the abutment surface. This procedure increases the mechanical interlock, thus improving its retention. The sandblasting promoted by Aluminum Oxide proves to be more efficient than other more sophisticated and complex procedures. ${ }^{24}$

In addition, this study analyzed the association between the sandblasting of abutment surface and the use of practice abutment cementing technique in this type of surface, showing promising results and easy clinical application. The results showed that the sandblasting promoted a significant increase in the tensile strength, observed in the two cementing techniques application. There is the advantage of no requirement for additional laboratory steps, such as making pipelines in the prosthetic crown for excess cement extravasation, ${ }^{25}$ or making an analog component based on a crown. ${ }^{26}$ Another advantage observed in the use of this technique lies in the fact that the tensile strength was equivalent, when compared to conventional cementing technique. The use of this technique in sandblasted surface increased the tensile strength, confirming data from the literature, in studies that analyzed the influence of Aluminum Oxide sandblasting on the retention force of the prosthetic crown. Furthermore, there is the advantage of decreasing the excess cement around the prosthetic crown, when the cementation is performed. ${ }^{11}$ The application of these two concepts allows an improvement on the cement-retained prosthesis treatment, since there is a reduction of excess cement, and an improvement of retention force.

This study has limitations because it is an in vitro study that, despite following a precise methodology based on other published studies, it needs a randomized clinical trial study to examine the positive effects of these maneuvers in real patients. The fact that the main advantage of practice 
abutment cementing technique is to have less cement remnants is not clinically validated; it also demands a clinical trial to prove this main advantage and its indication. The use of only one cement was necessary to avoid possible interactions between the cementing techniques, the abutment surface roughness and the cement, which could mask the real effects of the sandblasting on the abutment surface. Another study limitation lies in the fact that the study did not analyze another abutment surface, such as Zirconium abutments, as their use is very present in the Implantology.

\section{CONCLUSIONS}

We conclude, under the conditions used in this in vitro study, that:

- The use of a cementing technique that reduces significantly the excess cement and does not affect its retention force had a significant increased tensile strength, when used in a sandblasted surface.

- The practice abutment cementing technique showed no significant differences with the control technique, regarding to the tensile strength, in the two surfaces (standard and sandblasted) used in the study.

\section{REFERENCES}

1. Singer A, Serfaty V. Cement-retained implant-supported fixed partial dentures: a 6-month to 3-year follow-up. Int J Oral Maxillofac Implants. 1996 Sep-Oct;11(5):645-9.

2. Andersson B, Odman P, Lindvall AM, Brånemark PI. Cemented single crowns on osseointegrated implants after 5 years: results from a prospective study on CeraOne. Int $\mathrm{J}$ Prosthodont. 1998 May-Jun;11(3):212-8.

3. Hebel KS, Gajjar RC. Cement-retained versus screw-retained implant restorations: achieving optimal occlusion and esthetics in implant dentistry. J Prosthet Dent. 1997 Jan;77(1):28-35. doi: 10.1016/Soo22-3913(97)70203-8.

4. Taylor TD, Agar Jr. Twenty years of progress in implant prosthodontics. J Prosthet Dent. 2002 Jul;88(1):89-95. doi: 10.1067/mpr.2002.126818.
5. Michalakis KX, Hirayama H, Garefis PD. Cement-retained versus screw-retained implant restorations: a critical review. Int J Oral Maxillofac Implants. 2003 Sep-Oct;18(5):719-28.

6. Mangano C, Mangano F, Piattelli A, Iezzi G, Mangano A, La Colla L. Prospective clinical evaluation of 307 single-tooth morse taper-connection implants: a multicenter study. Int J Oral Maxillofac Implants. 2010 Mar-Apr;25(2):394-400.

7. Mangano C, Iaculli F, Piattelli A, Mangano F. Fixed restorations supported by Morse-taper connection implants: a retrospective clinical study with 10-20 years of follow-up. Clin Oral Implants Res. 2015 Oct;26(10):1229-36. doi:10.1111/clr.12439.

8. Pauletto N, Lahiffe BJ, Walton JN. Complications associated with excess cement around crowns on osseointegrated implants: a clinical report. Int J Oral Maxillofac Implants. 1999 Nov-Dec;14(6):865-8.

9. Gapski R, Neugeboren N, Pomeranz AZ, Reissner MW. Endosseous implant failure influenced by crown cementation: a clinical case report. Int J Oral Maxillofac Implants. 2008 Sep-Oct;23(5):943-6.

10. Dumbrigue HB, Abanomi AA, Cheng LL. Techniques to minimize excess luting agent in cement-retained implant restorations. J Prosthet Dent. 2002 Jan;87(1):112-4. doi: 10.1067/ mpr.2002.119418.

11. Santosa RE, Martin W, Morton D. Effects of a cementing technique in addition to luting agent on the uniaxial retention force of a single-tooth implant-supported restoration: an in vitro study. Int J Oral Maxillofac Implants. 2010 Nov-Dec;25(6):1145-52.

12. Kim Y, Yamashita J, Shotwell JL, Chong KH, Wang HL. The comparison of provisional luting agents and abutment surface roughness on the retention of provisional implant-supported crowns. J Prosthet Dent. 2006 Jun;95(6):450-5. doi: 10.1016/j.prosdent.2006.03.020.

13. Cano-Batalla J, Soliva-Garriga J, Campillo-Funollet M, Munoz-Viveros CA, Giner-Tarrida L. Influence of abutment height and surface roughness on in vitro retention of three luting agents. Int J Oral Maxillofac Implants. 2012;27(1):36-41.

14. Campos TN, Adachi LK, Miashiro K, Yoshida H, Shinkai RS, Neto PT, et al. Effect of surface topography of implant abutments on retention of cemented single-tooth crowns. Int J Periodontics Restorative Dent. 2010 Aug;30(4):409-13.

15. Oilo G, Jørgensen KD. The influence of surface roughness on the retentive ability of two dental luting cements. J Oral Rehabil. 1978 Oct;5(4):377-89. doi: 10.1111/j.1365-2842.1978.tbo1257.x. 
16. Sahu N, Lakshmi N, Azhagarasan NS, Agnihotri Y, Rajan M, Hariharan R. Comparison of the effect of implant abutment surface modifications on retention of implant-supported restoration with a polymer based cement. J Clin Diagn Res. 2014 Jan;8(1):239-42. doi: 10.7860/ JCDR/2014/7877.3931.

17. Michalakis KX, Pissiotis AL, Hirayama H. Cement failure loads of 4 provisional luting agents used for the cementation of implant-supported fixed partial dentures. Int J Oral Maxillofac Implants. 2000 Jul-Aug;15(4):545-9.

18. Sailer I, Mühlemann S, Zwahlen M, Hämmerle CH, Schneider D. Cemented and screw-retained implant reconstructions: a systematic review of the survival and complication rates. Clin Oral Implants Res. 2012 Oct;23(Suppl 6):163-201. doi:10.1111/ j.1600-0501.2012.02538.x.

19. Wilson TG Jr. The positive relationship between excess cement and peri-implant disease: a prospective clinical endoscopic study. J Periodontol. 2009 Sep;80(9):1388-92. doi: 10.1902/jop.2009.090115.

20. Korsch M, Obst U, Walther W. Cement-associated peri-implantitis: a retrospective clinical observational study of fixed implant-supported restorations using a methacrylate cement. Clin Oral Implants Res. 2014 Jul;25(7):797-802. doi: 10.1111/ clr.12173.
21. Linkevicius T, Vindasiute E, Puisys A, Peciuliene V. The influence of margin location on the amount of undetected cement excess after delivery of cement-retained implant restorations. Clin Oral Implants Res. 2011 Dec;22(12):1379-84. doi: 10.1111/j.1600-0501.2010.02119.x.

22. Agar JR, Cameron SM, Hughbanks JC, Parker MH. Cement removal from restorations luted to titanium abutments with simulated subgingival margins. J Prosthet Dent. 1997;78(1):43-7.

23. Zidan O, Ferguson GC. The retention of complete crowns prepared with three different tapers and luted with four different cements. J Prosthet Dent. 2003 Jun;89(6):565-71.

24. Kurt M, Külünk T, Ural C, Külünk Ş, Danişman Ş, Savaş S. The effect of different surface treatments on cement-retained implant-supported restorations. J Oral Implantol. 2013 Feb;39(1):44-51. doi: 10.1563/AAID-JOI-D-10-00151.

25. Schwedhelm ER, Lepe X, Aw TC. A crown venting technique for the cementation of implant-supported crowns. J Prosthet Dent. 2003 Jan;89(1):89-90. doi: 10.1067/ mpr.2003.66.

26. Yuzbasioglu E. A modified technique for extraoral cementation of implant retained restorations for preventing excess cement around the margins. J Adv Prosthodont. 2014;6(2):146-9. 